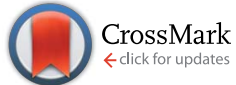

Cite this: Chem. Sci., 2017, 8, 600

Received 3rd August 2016

Accepted 30th August 2016

DOI: $10.1039 / \mathrm{c} 6 \mathrm{sc03450k}$

www.rsc.org/chemicalscience

\title{
Carbon dioxide binding at a Ni/Fe center: synthesis and characterization of $\mathrm{Ni}\left(\eta^{1}-\mathrm{CO}_{2}-\kappa \mathrm{C}\right)$ and $\mathrm{Ni}-\mu-$ $\mathrm{CO}_{2}-\kappa C: \kappa^{2} \mathrm{O}, \mathrm{O}^{\prime}-\mathrm{Fe} \dagger$
}

\author{
Changho Yoo and Yunho Lee*
}

\begin{abstract}
The degree of $\mathrm{CO}_{2}$ activation can be tuned by incorporating a distinct electronic coordination environment at the nickel center. A mononuclear nickel carboxylate species $\left(\mathrm{Ni}-\mathrm{CO}_{2}, 3\right)$ and a dinuclear nickel-iron carboxylate species $\left(\mathrm{Ni}-\mathrm{CO}_{2}-\mathrm{Fe}, 5\right)$ were prepared. The structure of 3 reveals a rare $\eta^{1}-\kappa \mathrm{C}$ binding mode of $\mathrm{CO}_{2}$, while that of 5 shows bridging $\mathrm{CO}_{2}$ binding $\left(\mu_{2}-\kappa C: \kappa^{2} \mathrm{O}, \mathrm{O}^{\prime}\right)$ between the nickel and iron, presented as the first example of a nickel- $\mu-\mathrm{CO}_{2}$-iron species. The structural analyses of 3 and 5 based on XRD and DFT data reveal a higher degree of $\mathrm{CO}_{2}$ activation in 5 , imparted by the additional interaction with an iron ion.
\end{abstract}

\section{Introduction}

Activation of carbon dioxide is currently receiving much attention due to its relevance to environmental and energy related issues. ${ }^{1}$ In the area of transition metal catalyzed reactions, one of the main challenges is selective reduction of $\mathrm{CO}_{2}$ to a product such as formate, carbon monoxide, methanol or methane. ${ }^{2}$ In a 2-electron process, the binding mode of the $\mathrm{CO}_{2}$ may determine the eventual product formation, e.g. formate vs. carbon monoxide. ${ }^{3}$ When the initial metal-oxygen interaction occurs to form a metal $\mathrm{CO}_{2}$ adduct $\mathrm{M}-\eta^{1}-\mathrm{CO}_{2}-\kappa O$, subsequent hydride transfer via $\mathrm{CO}_{2}$ addition to a $\mathrm{M}-\mathrm{H}$ bond generates a metalformate species. Alternatively, the metal-carbon bond formation can produce a metallacarboxylate species $\left(\mathrm{M}-\eta^{1}-\mathrm{CO}_{2}-\kappa C\right)$, followed by $\mathrm{C}-\mathrm{O}$ bond cleavage to generate $\mathrm{CO}$. In the latter case, an additional Lewis acid interaction can stabilize the negative charges at the oxygen atoms of the bound $\mathrm{CO}_{2} \cdot{ }^{4,5}$ Therefore, $\mathrm{CO}_{2}$ activation with a bimetallic system can be one way to guide the selectivity of the $\mathrm{CO}_{2}$ catalyst and is receiving much attention. ${ }^{5,6}$ In fact, an excellent example of a bimetallic center utilized in an efficient catalytic conversion of $\mathrm{CO}_{2}$ can be found in the active site of carbon monoxide dehydrogenase $(\mathrm{CODH}){ }^{7}$ According to recent studies, $\mathrm{CO}_{2}$ coordination at a heterobimetallic nickel-iron active site can be found in CODH's intermediate species, which possesses a $\mathrm{Ni}-\mu-\mathrm{CO}_{2}-\mathrm{Fe}$ moiety, Scheme $1 .^{8}$ Although X-ray analysis provides a structural snapshot of the $\mathrm{CO}_{2}$ reduction sequence, the role of the unique

Department of Chemistry, Korea Advanced Institute of Science and Technology (KAIST), Daejeon 34141, Republic of Korea. E-mail: yunholee@kaist.ac.kr; Fax: +82 42350 2810; Tel: +82423502814

$\dagger$ Electronic supplementary information (ESI) available: Characterization data for 3 and 5. CCDC 1492006 and 1492007. For ESI and crystallographic data in CIF or other electronic format see DOI: 10.1039/c6sc03450k iron ion is currently not well-understood. ${ }^{7}$ Thus, acquiring an understanding of iron assisted $\mathrm{CO}_{2}$-nickel coordination is of fundamental interest and is crucial for gaining mechanistic insight into this and other enzymatic reactions.

In organonickel chemistry, there are few mononuclear Ni- $\eta^{2}$ $\mathrm{CO}_{2}$ adducts possessing both $\mathrm{M}-\mathrm{C}$ and $\mathrm{M}-\mathrm{O}$ bonds. ${ }^{9}$ In 1975, Aresta and co-workers reported the first structurally characterized nickel- $\mathrm{CO}_{2}$ adduct $\left(\mathrm{PCy}_{3}\right)_{2} \mathrm{Ni}\left(\eta^{2}-\mathrm{CO}_{2}\right)$, Scheme 1.9 ${ }^{9 a}$ An analogous complex, (dtbpe)Ni $\left(\eta^{2}-\mathrm{CO}_{2}\right)$ (dtbpe $=1,2$-bis(di-tertbutylphosphino)ethane) was recently reported by Hillhouse and co-workers. ${ }^{9 d}$ More recently, our group reported a similar but unique five-coordinate nickel- $\mathrm{CO}_{2}$ adduct $\left(\mathrm{PP}^{\mathrm{Me}} \mathrm{P}\right) \mathrm{Ni}\left(\eta^{2}-\mathrm{CO}_{2}\right)$ $\left(\mathrm{PP}^{\mathrm{Me}} \mathrm{P}=\mathrm{PMe}\left(2-\mathrm{P}^{\mathrm{i}} \mathrm{Pr}_{2}-\mathrm{C}_{6} \mathrm{H}_{4}\right)_{2}\right) \cdot{ }^{9 f}$ According to its structural analysis, the five coordinate nickel $\mathrm{CO}_{2}$ species supported by three neutral $\mathrm{P}$ donors has a weak Ni-O bond available for electrophilic attack. ${ }^{9 f}$ Additionally, by utilizing an anionic tridentate PNP ligand $\left(\mathrm{PNP}^{-}=\mathrm{N}\left[2-\mathrm{P}^{\mathrm{i}} \mathrm{Pr}_{2}-4-\mathrm{Me}^{-} \mathrm{C}_{6} \mathrm{H}_{3}\right]_{2}{ }^{-}\right.$), our group reported the nickel hydroxycarbonyl species (PNP)NiCOOH (1), (PNP)NiCOONa (2) and $\left\{(\mathrm{PNP}) \mathrm{Ni}_{2}-\mu-\mathrm{CO}_{2}-\kappa^{2} C, O\right.$ (4), the first examples of $\mathrm{Ni}-\mathrm{CO}_{2}$ complexes that reveal a $\mathrm{Ni}-\mathrm{CO}_{2}-\kappa \mathrm{C}$ binding mode, Scheme $2 .^{10}$ The carboxylate group in these species is stabilized by a Lewis acid such as a proton, sodium or another nickel ion. Our interest then moved to comparing $\left(\mathrm{PP}^{\mathrm{Me}} \mathrm{P}\right) \mathrm{Ni}-$

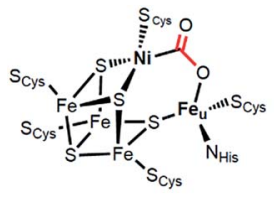

$\mathrm{CO}_{2}$ bound $\mathrm{CODH}$ active site

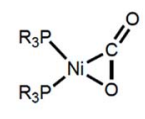

Aresta, Aresta,
Hillhouse

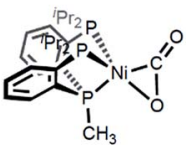

Lee
Scheme 1 The active site of carbon monoxide dehydrogenase (CODH, left), and 4- and 5-coordinate nickel $\mathrm{CO}_{2}$ adducts (right). 


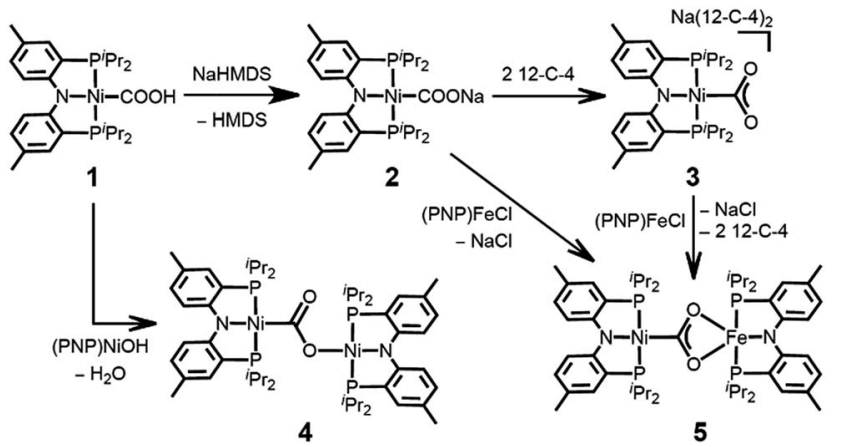

Scheme 2 Preparation of mononuclear- and dinuclear- $\mathrm{CO}_{2}$ adducts.

$\mathrm{CO}_{2}$ and (PNP)Ni-CO $\mathrm{CO}_{2}$ to evaluate their fundamental differences in $\mathrm{CO}_{2}$ activation. The different geometries favored with a $\mathrm{PP}^{\mathrm{Me}} \mathrm{P}$ or PNP ligand affect the identity of the nickel- $\mathrm{CO}_{2}$ moiety, which can be $\mathrm{Ni}(\mathrm{II})-\mathrm{CO}_{2}{ }^{2-}$ or $\mathrm{Ni}(0)-\mathrm{CO}_{2}$ or an open-shell $\mathrm{Ni}(\mathrm{I})-\mathrm{CO}_{2}{ }^{--}$, vide infra. Furthermore, by isolating the native nickel- $\mathrm{CO}_{2}$ species, we can further study the effect of the second iron ion. Although several nickel carboxylate species are already known, iron has never been introduced synthetically into a $\mathrm{Ni}-$ $\mathrm{CO}_{2}$ moiety.

Here, we present a nickel carboxylate species $\left\{\mathrm{Na}(12-\mathrm{C}-4)_{2}\right\}$ $\left\{(\mathrm{PNP}) \mathrm{Ni}-\eta^{1}-\mathrm{CO}_{2}-\kappa C\right\}(3)$, in which the nickel- $\mathrm{CO}_{2}$ moiety does not have any Lewis acid interactions. We also prepared a dinuclear nickel-iron carboxylate species (PNP)Ni- $\mu-\mathrm{CO}_{2}-\kappa C: \kappa^{2} O, O^{\prime}-$ $\mathrm{Fe}(\mathrm{PNP})$ (5), reminiscent of the NiFe-binuclear active site of CODH. This is an unprecedented example of a nickel-iron hetero-bimetallic complex possessing a bridging $\mathrm{CO}_{2}$ ligand. The levels of $\mathrm{CO}_{2}$ activation in compounds $\mathbf{3}$ and $\mathbf{5}$ are compared with other $\mathrm{Ni}-\mathrm{CO}_{2}$ adducts and the $\mathrm{Ni}-\mu-\mathrm{CO}_{2}-\mathrm{Fe}$ moiety found in $\mathrm{CODH}$.

\section{Results and discussion}

\section{Synthesis and characterization of the $\mathrm{Ni}-\eta^{1}-\mathrm{CO}_{2}-\kappa C$ complex}

The coordination of a hydroxycarbonyl moiety via a Ni-C bond was previously realized at a divalent nickel center supported by a PNP ligand.$^{10}$ Following deprotonation of (PNP)NiCOOH (1), its anionic congener (PNP)NiCOONa (2) was also prepared and recently reported by our group. ${ }^{10}$ The X-ray structure reveals that two molecules of 2 are oriented to form a pair with ionic interactions with two sodium ions in the crystal lattice, Fig. $1 .^{11}$ The corresponding $\mathrm{CO}_{2}$ ligand coordinates to the nickel center in a $\mu_{3}-\kappa^{1} C: \kappa^{2} O, O^{\prime}: \kappa^{1} O^{\prime}$ mode with a Ni-C1 bond distance of 1.882(1) A. There are additional bonds of the $\mathrm{CO}_{2}$ moiety to sodium ions with $\mathrm{Na}-\mathrm{O}$ bond distances of 2.352(1), 2.217(1) and $2.459(1) .{ }^{11}$ To obtain a sodium-free adduct, 2 equiv. of 12 -crown4 was added to a solution of 2 , resulting in the formation of $\left.\left\{\mathrm{Na}(12-\mathrm{C}-4)_{2}\right\}(\mathrm{PNP}) \mathrm{Ni}-\eta^{1}-\mathrm{CO}_{2}-\kappa C\right\}(3)$. The crystal structure of 3 revealed the successful generation of a mononuclear nickel adduct possessing an $\eta^{1}-\kappa C$ coordinated carbon dioxide species with a Ni-C bond distance of 1.911(2) $\AA$, as shown in Fig. 1 and Table 1 . The oxidation state of the nickel ion in 3 can be assigned as $2+$ based on its similar structural features to

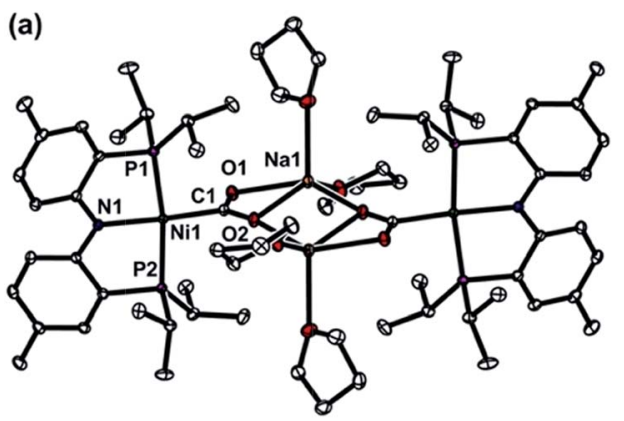

(b)
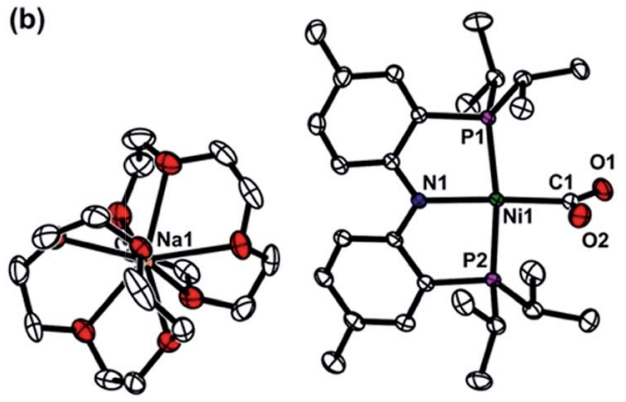

Fig. 1 Displacement ellipsoid (50\%) representations for (a) (PNP) $\mathrm{NiCOONa}(2)$ in a dimeric assembly with co-crystallized THF molecules, ${ }^{11}$ and (b) $\left\{\mathrm{Na}(12-\mathrm{C}-4)_{2}\right\}\left\{(\mathrm{PNP}) \mathrm{Ni}-\eta^{1}-\mathrm{CO}_{2}-\kappa \mathrm{C}\right\}$ (3). A co-crystallized 12-crown-4 molecule and hydrogen atoms are omitted for clarity.

previously known nickel(II) species such as (PNP)NiCOOH (1) and $\left\{(\mathrm{PNP}) \mathrm{Ni}_{2}-\mu-\mathrm{CO}_{2}-\kappa^{2} \mathrm{C}, \mathrm{O}(\mathbf{4})\right.$, vide infra. The geometry of 3 is square planar $\left(\tau_{4}=0.12^{12}\right)$ with a similar but slightly elongated $\mathrm{Ni}-\mathrm{C}$ bond distance in comparison to those of $\mathbf{1}$ and $\mathbf{4}\left(d_{\mathrm{Ni}-\mathrm{C}}=\right.$ 1.866(2) and 1.888(2) $\AA$, respectively, Table 1). This is probably due to a lower degree of $\pi$ back-bonding between the nickel and $\mathrm{CO}_{2}$. In fact, $\pi$ back-donation from the nickel center to a $\mathrm{CO}_{2}$ ligand in such nickel carboxylate species is indicated by shorter Ni-C distances (1.858-1.911 ̊̊) than those of the nickel alkyl species (PNP)NiR ( $\left.\mathrm{R}=\mathrm{Me}, \mathrm{Et},{ }^{n} \mathrm{Pr}\right)(1.963-2.004 \AA) .{ }^{13}$ The molecular orbitals generated from DFT calculations also show the presence of $\pi$ back-donation from the Ni $\mathrm{d}_{x z}$ to the $\mathrm{CO}_{2} \pi^{*}$ orbital (see ESI $\dagger$ ). Due to the absence of Lewis acid interactions in 3, a lower $\pi$-accepting ability of the $\mathrm{CO}_{2}$ ligand is expected. Its structural data also revealed that the plane of the $\mathrm{CO}_{2}$ ligand is perpendicular to that of the square planar (PNP)Ni moiety. One of the oxygen atoms $\left(d_{\mathrm{Ni1}-\mathrm{O} 2}=2.614(1) \AA\right)$ is slightly closer to the nickel center than the other $\left(d_{\mathrm{Ni1}-\mathrm{O} 1}=2.776(1) \AA\right)$, Table 2 . These $\mathrm{Ni}-\mathrm{O}$ distances are much longer than those for other known Ni- $\eta^{2}-\mathrm{CO}_{2}$ adducts (1.9-2.2 $\AA$, Table 2), suggesting that neither of the oxygen atoms are bound. ${ }^{9}$ The DFT analysis also supports minimal interaction between the nickel and oxygen atoms (Wiberg index $=0.1358$ for Ni1-O2 and 0.1679 for Ni1$\mathrm{O} 1$, see Table 2). The two $\mathrm{C}-\mathrm{O}$ bond distances are nearly identical $\left(d_{\mathrm{C} 1-\mathrm{O} 1}=1.247(2) \AA, d_{\mathrm{C} 1-\mathrm{O} 2}=1.248(2) \AA\right.$, Table 1$)$ and slightly shorter than in the analogous carboxylate complexes 2 and 4 (Table 1), due to the absence of a Lewis acid, Na or Ni. According to the DFT analysis, the HOMO of 3 possesses contributions from both a nickel $\mathrm{d}_{x^{2}-y^{2}}$ orbital and a $\mathrm{CO}_{2} \pi^{*}$ orbital, see Fig. 2. Due to additional electron density from 
Table 1 Selected bond distances and angles for the nickel carboxylate species 1, 2, 3, 4 and 5, and $\mathrm{CO}_{2}$-bound $\mathrm{CODH}$

\begin{tabular}{|c|c|c|c|c|c|c|}
\hline & $1^{10}$ & $2^{11}$ & 3 & $4^{10}$ & 5 & $\mathrm{CODH}^{8 b}$ \\
\hline$d_{\mathrm{Ni}-\mathrm{C}}(\AA)$ & $1.866(2)$ & $1.882(1)$ & $1.911(2)$ & $1.888(2)$ & $1.858(1)$ & $1.805(31)$ \\
\hline \multirow{2}{*}{$d_{\mathrm{M}-\mathrm{O}}(\AA)$} & - & $2.352(1)^{a}$ & - & $1.897(2)^{b}$ & $2.204(1)^{c}$ & $2.030(18)^{c}$ \\
\hline & & $2.459(1)^{a}$ & & & & \\
\hline \multirow[t]{2}{*}{$d_{\mathrm{C}-\mathrm{O}}(\AA)$} & $1.269(3)$ & $1.260(1)$ & $1.247(2)$ & $1.240(3)$ & $1.269(2)$ & $1.298(30)$ \\
\hline & $1.313(3)$ & $1.271(1)$ & $1.248(2)$ & $1.296(3)$ & $1.289(2)$ & $1.316(30)$ \\
\hline
\end{tabular}

$\mathrm{CO}_{2}{ }^{2-}$ being shifted to the nickel, the $\mathrm{CO}_{2}$ moiety is slightly oxidized compared to the $\mathrm{sp}^{2}$ hybridized carboxylate ligands found in 2 and 4 . The larger $\mathrm{O}-\mathrm{C}-\mathrm{O}$ angle $\left(128.4(2)^{\circ}\right)$ of 3 compared to others $\left(124.0(1)\right.$ and $\left.123.7(2)^{\circ}\right)$ also supports this electronic feature, vide infra. Although an $\eta^{1}-\kappa C \mathrm{CO}_{2}$ coordination mode has been proposed for many $\mathrm{CO}_{2}$ reduction strategies, $^{2,3}$ the only example of a crystallographically identified metal $\eta^{1}-\kappa C \mathrm{CO}_{2}$ complex is a rhodium $\mathrm{CO}_{2}$ adduct, $\mathrm{Rh}\left(\mathrm{CO}_{2}\right)$ $(\mathrm{Cl})(\text { diars })_{2}($ diars $=o$-phenylene-bis(dimethylarsine $)$ ), reported by the Herskovitz group. ${ }^{14}$ According to their $\mathrm{C}-\mathrm{O}$ bond distances $\left(1.20(2)\right.$ and 1.25(2) $\AA$ ) and O-C-O angle $\left(126(2)^{\circ}\right)$, the $\mathrm{CO}_{2}$ moiety in 3 shares similar structural and electronic features. Thus, compound 3 is a unique example possessing $\eta^{1}$ $\kappa C \mathrm{CO}_{2}$ binding, since such a binding mode is unknown for $1^{\text {st }}$ row transition metals and is rare in structurally characterized metal- $\mathrm{CO}_{2}$ adducts.

\section{Synthesis and characterization of the heterobimetallic nickel-} iron $\mathrm{CO}_{2}$ complex

To gain a better understanding of the role of the second metal ion in the $\mathrm{CODH}$ active site, we prepared a heterobimetallic nickel-iron carboxylate species possessing a $\mathrm{Ni}-\mathrm{CO}_{2}-\mathrm{Fe}$

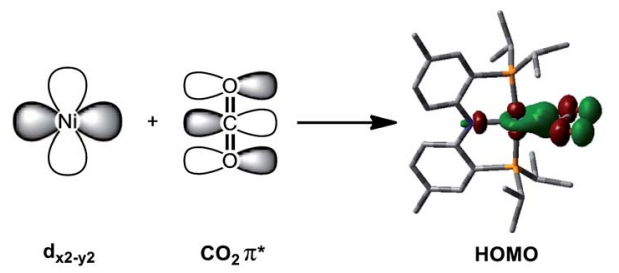

Fig. 2 Combination of the $\mathrm{Nid} \mathrm{d}^{2}-y^{2}$ and $\mathrm{CO}_{2} \pi^{*}$ orbitals provides the DFT calculated HOMO of $\left\{\mathrm{Na}(12-\mathrm{C}-4)_{2}\right\}\left\{(\mathrm{PNP}) \mathrm{Ni}-\eta^{1}-\mathrm{CO}_{2}-\kappa \mathrm{C}\right\}$ (3).

fragment by addition of $\{(\mathrm{PNP}) \mathrm{Fe}\}^{+}$to a Ni- $\eta^{1}-\mathrm{CO}_{2}-\kappa C$ species. To a yellow solution of $\left\{\mathrm{Na}(12-\mathrm{C}-4)_{2}\right\}\left\{(\mathrm{PNP}) \mathrm{Ni}-\eta^{1}-\mathrm{CO}_{2}-\kappa C\right\}(3)$ in toluene, a purple solution of (PNP)FeCl was added. The immediate formation of a new orange species (PNP)Ni- $\mu-\mathrm{CO}_{2}$ $\kappa C: \kappa^{2} O, O^{\prime}-\mathrm{Fe}(\mathrm{PNP})(5)$ was confirmed, using the ${ }^{1} \mathrm{H}$ NMR spectrum, from the absence of peaks for 3 and (PNP)FeCl and the presence of new paramagnetically shifted signals. The same product was also prepared by substitution of the sodium ion of (PNP)NiCOONa (2) with (PNP)FeCl. The solid-state structure of 5 clearly revealed a dinuclear nickel-iron complex with a bridging $\mathrm{CO}_{2}$ ligand in the $\mu_{2}-\kappa C: \kappa^{2} O, O^{\prime}$ mode (Fig. 3). The Ni and Fe ions are separated by a distance of $4.3690(3) \AA$ A. The two C-O bond

Table 2 Selected physical parameters and bond indices from the natural bond orbital analysis

\begin{tabular}{|c|c|c|c|c|c|}
\hline & $\mathrm{Ni}\left(\mathrm{PCy}_{3}\right)_{2}\left(\eta^{2}-\mathrm{CO}_{2}\right)^{9 a}$ & (dtbpe) Ni $\left(\eta^{2}-\mathrm{CO}_{2}\right)^{9 d}$ & $\left(\mathrm{PP}^{\mathrm{Me}} \mathrm{P}\right) \mathrm{Ni}\left(\eta^{2}-\mathrm{CO}_{2}\right)^{9 f}$ & 3 & 5 \\
\hline \multicolumn{6}{|c|}{ Structural parameters } \\
\hline$d_{\mathrm{Ni}-\mathrm{C}}(\AA)$ & \multirow{2}{*}{$\begin{array}{l}1.84(2) \\
1.99(2)\end{array}$} & $1.868(2)$ & $1.904(1)$ & $1.911(2)$ & $1.858(1)$ \\
\hline & & $1.904(2)$ & $2.191(1)$ & $2.776(1)$ & $2.792(1)$ \\
\hline \multirow[t]{2}{*}{$d_{\mathrm{C}-\mathrm{O}}(\AA)$} & $1.17(2)$ & $1.200(3)$ & $1.218(2)$ & $1.248(2)$ & $1.269(2)$ \\
\hline & $1.22(2)$ & $1.266(3)$ & $1.252(2)$ & $1.247(2)$ & $1.289(2)$ \\
\hline \multicolumn{6}{|c|}{ Wiberg bond indices ${ }^{a}$} \\
\hline $\mathrm{Ni}-\mathrm{C}$ & - & 0.5766 & 0.5286 & 0.6143 & 0.6277 \\
\hline \multirow[t]{2}{*}{$\mathrm{Ni}-\mathrm{O}$} & \multirow[t]{2}{*}{-} & \multirow[t]{2}{*}{0.4300} & \multirow[t]{2}{*}{0.3117} & 0.1679 & 0.0798 \\
\hline & & & & 0.1358 & 0.0644 \\
\hline $\mathrm{C}-\mathrm{O}$ & - & 1.6927 & 1.6384 & 1.5112 & 1.3993 \\
\hline
\end{tabular}

${ }^{a}$ Wiberg bond indices were calculated using single-point calculations, for which geometries were obtained from the XRD data. 


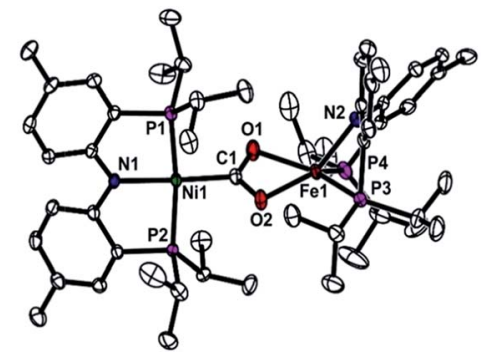

Fig. 3 Displacement ellipsoid (50\%) representation for (PNP)Ni- $\mu-$ $\mathrm{CO}_{2}-\kappa C: \kappa^{2} \mathrm{O}, \mathrm{O}^{\prime}-\mathrm{Fe}(\mathrm{PNP})(5)$. Hydrogen atoms are omitted for clarity.

distances are 1.269(2) and 1.289(2) $\AA$, revealing that a significant elongation has occurred due to the iron interaction compared to 3 (Table 1). The bond distances between the iron and both oxygen atoms are 2.204(1) and 2.066(1) ̊. The nickel center possesses a square planar geometry $\left(\tau_{4}=0.10^{12}\right)$. The geometry around the iron is distorted square pyramidal $\left(\tau=0.13,{ }^{15} \mathrm{Fig} .3\right)$. The $01-\mathrm{C} 1-\mathrm{O} 2$ angle $\left(116.5^{\circ}\right)$ reflects the $\mathrm{sp}^{2}$ hybridization of the carboxylate ligand in $\mathbf{5}$. In fact, recent crystallographic data of $\mathrm{CODH}$ at atomic resolution $\left(d_{\min }=1.03 \AA\right)$ revealed that the bound $\mathrm{CO}_{2}$ molecule $\left(\angle \mathrm{O}-\mathrm{C}-\mathrm{O}=117.2(26)^{\circ}\right)$ is a carboxylate anion $\left(\mathrm{CO}_{2}{ }^{2-}\right){ }^{8 b, 8 c}$ Regarding the similarity between these angles, the carboxylate moiety in 5 might be close to $\mathrm{CO}_{2}{ }^{2-}$. The asymmetric vibration for $\mathrm{CO}_{2}$ observed at $1510 \mathrm{~cm}^{-1}$, which is similar to that observed for the dinickel carboxylate species (4) at $1518 \mathrm{~cm}^{-1}$, also indicates a reduced state of $\mathrm{CO}_{2}$. The effective magnetic moment of $\mathbf{5}$ was determined using the Evans' method $\left(\mu_{\text {eff }}=4.95 \mu_{\mathrm{B}}\right.$ in $\left.\mathrm{C}_{6} \mathrm{D}_{6}\right)$, which indicated an $S=2$ spin state. ${ }^{16}$ According to DFT calculations, most of the spin density is located on the iron center (see ESI $\dagger$ ). For CODH, the unique iron, $\mathrm{Fe}_{\mathrm{u}}$, was assigned as a high spin iron(II) (ferrous component II, FCII) using Mössbauer spectroscopy ${ }^{17}$ and a low-spin nickel(II) was demonstrated using X-ray absorption spectroscopy (XAS). ${ }^{18}$ The current structural and spectroscopic analyses suggest that $\mathbf{5}$ might share a similar electronic structure to that found in $\mathrm{CODH}$. Gibson classified the $\mu_{2}-\kappa C: \kappa^{2} O, O^{\prime}$ binding modes of $\mathrm{CO}_{2}$ into two types according to the difference between the two C-O distances. ${ }^{19}$ Due to the two similar $\mathrm{C}-\mathrm{O}$ distances of the $\mathrm{CO}_{2}$ moiety, compound $5\left(\Delta d_{\mathrm{C}-\mathrm{O}}=0.020 \AA\right)$ can be assigned as a class I complex. ${ }^{20}$ In the dinickel $\mathrm{CO}_{2}$ species (4), the $\mathrm{CO}_{2}$ molecule is coordinated in a $\mu_{2}-\kappa C: \kappa O$ mode with the absence of a Ni2-O2 interaction $\left(d_{\mathrm{Ni2}-\mathrm{O} 2}=3.14(7)\right)$ and two different $\mathrm{C}-\mathrm{O}$ bond distances $\left(\Delta d_{\mathrm{C}-\mathrm{O}}=0.056 \AA\right)$. In $\mathrm{CODH}, \mathrm{CO}_{2}$ is coordinated in a $\mu_{2}-\kappa C: \kappa O$ fashion between the nickel and iron ions, but the two $\mathrm{C}-\mathrm{O}$ bond distances are quite comparable $\left(\Delta d_{\mathrm{C}-\mathrm{O}}=0.018 \AA\right)$, akin to the $\mu_{2}-\kappa C: \kappa^{2} O, O^{\prime}$ mode. This might be due to hydrogen bonding with the protein matrix, since both the $\mathrm{CO}_{2}$ oxygens are hydrogen bonded to His93 and Lys563, respectively. ${ }^{8}$

Compound 5 is the first example of a dinuclear nickel-iron$\mathrm{CO}_{2}$ complex. While dinuclear $\mathrm{CO}_{2}$ complexes mostly employ $2^{\text {nd }}$ and $3^{\text {rd }}$ row transition metals, ${ }^{19}$ several bimetallic iron carboxylates $\left(\mathrm{Fe}-\mathrm{CO}_{2}-\mathrm{M}, \mathrm{M}=\mathrm{Ti}, \mathrm{Zr}, \mathrm{Sn}, \mathrm{Re}\right)$ have been reported. ${ }^{5 a, 5 c-e, 21}$ However, such complexes typically possess an $\mathrm{Fe}-\mathrm{C}$ bond rather than an $\mathrm{Fe}-\mathrm{O}$ bond with $\mathrm{CO}_{2}$. There have been numerous examples of nickel-iron bimetallic complexes reported for synthetic model studies of NiFe hydrogenase, ${ }^{22}$ but a bimetallic complex possessing a $\mathrm{Ni}-\mu-\mathrm{CO}_{2}$-Fe moiety closely related to $\mathrm{CODH}$ chemistry is not known. The Holm group constructed a series of $\left[\mathrm{NiFe}_{3} \mathrm{~S}_{4}\right]$ cubanes as structural model complexes for the $\left[\mathrm{NiFe}_{4} \mathrm{~S}_{4}\right]$ core in $\mathrm{CODH}{ }^{23}$ However, the installation of an iron species corresponding to the $\mathrm{Fe}_{\mathrm{u}}$ in $\mathrm{CODH}$ and reactions involving $\mathrm{CO}$ and $\mathrm{CO}_{2}$ have not yet been investigated. More recently, the Holm group also reported a bimetallic complex containing nickel and iron supported by a binucleating macrocycle. ${ }^{24}$ With respect to CODH chemistry, bridging hydoroxo, cyanido and formato species have been generated, however, a Ni- $\mu-\mathrm{CO}_{2}-\mathrm{Fe}$ fragment had not yet been isolated.

\section{Activation of $\mathrm{CO}_{2}$ in 3 and 5}

Previously known 4-coordinate $\mathrm{Ni}-\mathrm{CO}_{2}$ complexes possessing an $\eta^{2}-\mathrm{CO}_{2}$ binding mode have a formally zero-valent nickel center, Scheme 1. ${ }^{9}$ This suggests limited $\mathrm{CO}_{2}$ activation in such species. Interestingly, the 5-coordinate nickel $\mathrm{CO}_{2}$ adduct $\left(\mathrm{PP}^{\mathrm{Me}} \mathrm{P}\right) \mathrm{Ni}\left(\mathrm{CO}_{2}\right)$ also has a similar level of activation of $\mathrm{CO}_{2}$ based on the $\mathrm{C}-\mathrm{O}$ bond distances and the $\mathrm{O}-\mathrm{C}-\mathrm{O}$ angle, Table 2. Regarding $\mathrm{CO}_{2}$ binding and activation, $\left\{\mathrm{Na}(12-\mathrm{C}-4)_{2}\right\}(\mathrm{PNP}) \mathrm{Ni}-$ $\left.\eta^{1}-\mathrm{CO}_{2}-\kappa C\right\}$ (3) is a unique example. It is striking that a neutral pincer-type ligand $\mathrm{PP}^{\mathrm{Me}} \mathrm{P}\left(\mathrm{PP}^{\mathrm{Me}} \mathrm{P}=\mathrm{PMe}\left[2-\mathrm{P}^{\mathrm{i}} \mathrm{Pr}_{2}-\mathrm{C}_{6} \mathrm{H}_{4}\right]_{2}\right)$ favors 5coordinate $\eta^{2}-\mathrm{CO}_{2}$ coordination at a single nickel center, while 3 remains as a 4-coordinate species with $\eta^{1}-\mathrm{CO}_{2}$ coordination. ${ }^{9 f}$ Although the total number of $\mathrm{Ni}$ d-electrons and $\mathrm{CO}_{2} \pi^{*}$-electrons in both 3 and $\left(\mathrm{PP}^{\mathrm{Me}} \mathrm{P}\right) \mathrm{Ni}\left(\mathrm{CO}_{2}\right)$ is the same, $\left(\mathrm{PP}^{\mathrm{Me}} \mathrm{P}\right) \mathrm{Ni}\left(\mathrm{CO}_{2}\right)$ can be considered as formally $\mathrm{Ni}(0)-\left(\mathrm{CO}_{2}\right)$ while 3 can be better described as a $\mathrm{Ni}(\mathrm{II})-\left(\mathrm{CO}_{2}{ }^{2-}\right)$ species. The asymmetric $\mathrm{CO}_{2}$ stretching frequency for 3 is significantly shifted to a lower vibration, $1620 \mathrm{~cm}^{-1}$, compared to those of the $\mathrm{Ni}-\eta^{2}-\mathrm{CO}_{2}$ complexes (Table 2), which is evidence of a reduced $\mathrm{CO}_{2}$ moiety in $3 .^{9}$ This may be due to the influence of the trans atom: an anionic amide nitrogen $v s$. a neutral phosphorus atom. The anionic nitrogen in 3 electrostatically favors a divalent nickel center, while the neutral $\pi$-acidic $\mathrm{P}$ atom in the $\mathrm{PP}^{\mathrm{Me}} \mathrm{P}$ ligand favors a $\mathrm{Ni}(0)$ center. In fact, the PNP ligand typically stabilizes a square planar geometry while the $\mathrm{PP}^{\mathrm{Me}} \mathrm{P}$ ligand favors a pseudo-tetrahedral geometry. Thus, 3 prefers to accommodate a divalent nickel center while $\left(\mathrm{PP}^{\mathrm{Me}} \mathrm{P}\right) \mathrm{Ni}\left(\mathrm{CO}_{2}\right)$ prefers $\mathrm{Ni}(0)$. However, the reduction state of the $\mathrm{CO}_{2}$ moiety in 3 is a little ambiguous according to the $\mathrm{O}-\mathrm{C}-\mathrm{O}$ angle. The $\mathrm{O}-\mathrm{C}-\mathrm{O}$ angle in 3 of $128.4(2)^{\circ}$ is larger than those of an ideal $\mathrm{sp}^{2}$ hybridized carbon $\left(120^{\circ}\right)$ and the other nickel(II) carboxylate species 1, 2 and $4\left(119.6(2)^{\circ}, 124.0(1)^{\circ}\right.$ and $123.7(2)^{\circ}$, respectively, Table 1$)$. The $\mathrm{O}-\mathrm{C}-\mathrm{O}$ angle of a $\mathrm{CO}_{2}$ radical anion $\left(\mathrm{CO}_{2}{ }^{--}\right)$is suggested to be $133^{\circ},{ }^{25}$ which is fairly similar to those of the previously reported Ni- $\eta^{2}-\mathrm{CO}_{2}$ complexes, Table 2 . Thus, the geometry of the $\mathrm{CO}_{2}$ moiety in 3 may be thought of as being between a $\mathrm{CO}_{2}$ radical anion and a carboxylate.

Upon addition of iron to compound 3, the $\mathrm{CO}_{2}$ is further reduced to carboxylate $\left(\mathrm{CO}_{2}{ }^{2-}\right)$. The $\mathrm{C}-\mathrm{O}$ bond distances and $\mathrm{O}-$ $\mathrm{C}-\mathrm{O}$ angle in 5 clearly show a 2-electron reduced state of the $\mathrm{CO}_{2}$ moiety, Table 2. This was also indicated by the asymmetric $\mathrm{CO}_{2}$ 
vibration observed at $1510 \mathrm{~cm}^{-1}$, which is significantly lower than those of other $\mathrm{CO}_{2}$ species and 3. The Wiberg bond indices nicely agree with the bond distances, Table 2 . These analyses of a series of nickel- $\mathrm{CO}_{2}$ compounds demonstrate how the degree of $\mathrm{CO}_{2}$ activation can be tuned by incorporating a distinct electronic coordination environment at the metal center, and may have parallels to the efficient $\mathrm{CO}_{2}$ conversion found in CODH.

In order to study further activation of the bound $\mathrm{CO}_{2}$ via $\mathrm{C}-\mathrm{O}$ bond cleavage, protonation of $\mathbf{3}$ and $\mathbf{5}$ was attempted. Our group previously reported that reversible $\mathrm{C}-\mathrm{O}$ bond cleavage/formation occurs with a nickel hydroxycarbonyl species (1). ${ }^{10}$ From reaction of 3 with 1 equiv. of $\mathrm{HBF}_{4} \cdot \mathrm{Et}_{2} \mathrm{O}$, a nickel hydroxycarbonyl species (1) was produced and isolated with a $74 \%$ yield. A similar reaction of 3 with 2 equiv. of $\mathrm{HBF}_{4} \cdot \mathrm{Et}_{2} \mathrm{O}$ resulted in the formation of a carbonyl species $\{(\mathrm{PNP}) \mathrm{NiCO}\}\left\{\mathrm{BF}_{4}\right\}$ in $75 \%$ yield, revealing that two sequential protonations can occur with compound 3 possessing a Ni- $\eta^{1}-\mathrm{CO}_{2}-\kappa C$ moiety, which are key steps in the transformation of $\mathrm{CO}_{2}$ to $\mathrm{CO}$. Although protonation of compound 5 seems to produce 1 and $\left.\{(\mathrm{PNP}) \mathrm{NiCO}\} \mathrm{BF}_{4}\right\}$, unfortunately, their yields were not clear due to thermal decomposition of $\mathbf{5}$ and the generation of multiple products. Demetallation of the iron seems to be one of the decomposition processes.

\section{Conclusions}

In conclusion, the generation of unprecedented nickel-carbon dioxide adducts possessing a $\mathrm{Ni}-\mathrm{C}$ bond accommodated by a (PNP)Ni scaffold was accomplished. A mononuclear $\mathrm{CO}_{2}$ adduct $\left.\left\{\mathrm{Na}(12-\mathrm{C}-4)_{2}\right\}(\mathrm{PNP}) \mathrm{Ni}-\eta^{1}-\mathrm{CO}_{2}-\kappa C\right\}$ (3) and a dinuclear nickel-iron carboxylate species (PNP)Ni- $\mu-\mathrm{CO}_{2}-\kappa C: \kappa^{2} O, O^{\prime}$ $\mathrm{Fe}(\mathrm{PNP})$ (5) were synthesized successfully. While the solid state structure of 3 revealed a rare $\eta^{1}-\kappa C$ binding mode, compound 5 was structurally characterized to reveal a unique class I type $\mu_{2}-$ $\kappa C: \kappa^{2} O, O^{\prime}$ binding mode. This heterobimetallic $\mathrm{CO}_{2}$ adduct is the first example of a nickel-iron carboxylate species, of which the structural and electronic features are reminiscent of those of the Ni- $\mu-\mathrm{CO}_{2}-\mathrm{Fe}$ fragment found in the C-cluster of $\mathrm{CODH}$. Comparison of the $\eta^{1}-\mathrm{CO}_{2}-\kappa C$ species 3 and dinuclear $\mathrm{Ni}-\mu-\mathrm{CO}_{2}-$ Fe species 5 with previously reported $\mathrm{Ni}-\mathrm{CO}_{2}$ adducts suggested that the $\mathrm{CO}_{2}$ ligand can be stabilized and activated by interaction with the second metal. Protonation of 3 produces a nickel carbonyl species $\left.\{(\mathrm{PNP}) \mathrm{NiCO}\} \mathrm{BF}_{4}\right\}$ via $\mathrm{C}-\mathrm{O}$ bond cleavage, while the reactivity of $\mathbf{5}$ is limited. Further studies on incorporating a stable iron species and the subsequent reactivity toward protonation are currently underway.

\section{Acknowledgements}

This work was supported by the C1 Gas Refinery Program (NRF2015M3D3A1A01064880) through the National Research Foundation of Korea (NRF-2015R1A2A2A01004197), and KAIST and the Aramco Overseas Company. This work was also supported by the Supercomputer Center/Korea Institute of Science and Technology (KSC-2015-S1-0005).

\section{Notes and references}

1 (a) Q. Liu, L. Wu, R. Jackstell and M. Beller, Nat. Commun., 2015, 6, 5933; (b) M. Aresta, A. Dibenedetto and A. Angelini, Chem. Rev., 2014, 114, 1709; (c) M. Aresta, Carbon Dioxide as Chemical Feedstock, Wiley-VCH, Weinheim, 2010.

2 (a) J. Qiao, Y. Liu, F. Hong and J. Zhang, Chem. Soc. Rev., 2014, 43, 631; (b) C. Finn, S. Schnittger, L. J. Yellowlees and J. B. Love, Chem. Commun., 2012, 48, 1392; (c) E. Fujita, Coord. Chem. Rev., 1999, 185-186, 373.

3 (a) J. Song, E. L. Klein, F. Neese and S. Ye, Inorg. Chem., 2014, 53, 7500; (b) M. R. Dubois and D. L. Dubois, Acc. Chem. Res., 2009, 42, 1974; (c) E. E. Benson, C. P. Kubiak, A. J. Sathrum and J. M. Smieja, Chem. Soc. Rev., 2009, 38, 89.

4 (a) M. Devillard, R. Declercq, E. Nicolas, A. W. Ehlers, J. Backs, N. Saffon-Merceron, G. Bouhadir, J. C. Slootweg, W. Uhl and D. Bourissou, J. Am. Chem. Soc., 2016, 138, 4917; (b) S. J. K. Forrest, J. Clifton, N. Fey, P. G. Pringle, H. A. Sparkes and D. F. Wass, Angew. Chem., Int. Ed., 2015, 54, 2223.

5 (a) M. Hirano, M. Akita, K. Tani, K. Kumagai, N. C. Kasuga, A. Fukuoka and S. Komiya, Organometallics, 1997, 16, 4206; (b) K. E. Litz, K. Henderson, R. W. Gourley and M. M. B. Holl, Organometallics, 1995, 14, 5008; (c) J. R. Pinkes, B. D. Steffey, J. C. Vites and A. R. Cutler, Organometallics, 1994, 13, 21; (d) J. R. Pinkes and A. R. Cutler, Inorg. Chem., 1994, 33, 759; (e) J. C. Vites, B. D. Steffey, M. E. Giuseppetti-Dery and A. R. Cutler, Organometallics, 1991, 10, 2827; (f) E. G. Lundquist, J. C. Huffman, K. Folting, B. E. Mann and K. G. Caulton, Inorg. Chem., 1990, 29, 128; (g) E. G. Lundquist, J. C. Huffman and K. G. Caulton, J. Am. Chem. Soc., 1986, 108, 8309; (h) S. Gambarotta, F. Arena, C. Floriani and P. F. Zanazzi, J. Am. Chem. Soc., 1982, 104, 5082; (i) G. Fachinetti, C. Floriani and P. F. Zanazzi, J. Am. Chem. Soc., 1978, 100, 7405.

6 (a) C. W. Machan and C. P. Kubiak, Dalton Trans., 2016, DOI: 10.1039/C6DT01956K, in press; (b) S. Bagherzadeh and N. P. Mankad, J. Am. Chem. Soc., 2015, 137, 10898; (c) O. Cooper, C. Camp, J. Pécaut, C. E. Kefalidis, L. Maron, S. Gambarelli and M. Mazzanti, J. Am. Chem. Soc., 2014, 136, 6716; (d) J. P. Krogman, B. M. Foxman and C. M. Thomas, J. Am. Chem. Soc., 2011, 133, 14582; (e) B. D. Steffey, C. J. Curtis and D. L. DuBois, Organometallics, 1995, 14, 4937.

7 M. Can, F. A. Armstrong and S. W. Ragsdale, Chem. Rev., 2014, 114, 4149.

8 (a) J.-H. Jeoung and H. Dobbek, Science, 2007, 318, 1461; (b) J. Fesseler, J.-H. Jeoung and H. Dobbek, Angew. Chem., Int. Ed., 2015, 54, 8560; (c) M. W. Ribbe, Angew. Chem., Int. Ed., 2015, 54, 8337.

9 (a) M. Aresta, C. F. Nobile, V. G. Albano, E. Forni and M. Manassero, J. Chem. Soc., Chem. Commun., 1975, 636; (b) M. Aresta and C. F. Nobile, J. Chem. Soc., Dalton Trans., 1977, 708; (c) A. Döhring, P. W. Jolly, C. Krüger and 
M. J. Romão, Z. Naturforsch., B:J. Chem. Sci., 1985, 40, 484; (d) J. S. Anderson, V. M. Iluc and G. L. Hillhouse, Inorg. Chem., 2010, 49, 10203; (e) R. Beck, M. Shoshani, J. Krasinkiewicz, J. A. Hatnean and S. A. Johnson, Dalton Trans., 2013, 42, 1461; (f) Y.-E. Kim, J. Kim and Y. Lee, Chem. Commun., 2014, 50, 11458.

10 C. Yoo, J. Kim and Y. Lee, Organometallics, 2013, 32, 7195.

11 C. Yoo and Y. Lee, Inorg. Chem. Front., 2016, 3, 849.

12 L. Yang, D. R. Powell and R. P. Houser, Dalton Trans., 2007, 955.

13 C. Yoo, S. Oh, J. Kim and Y. Lee, Chem. Sci., 2014, 5, 3853.

14 J. C. Calabrese, T. Herskovitz and J. B. Kinney, J. Am. Chem. Soc., 1983, 105, 5914.

15 A. W. Addison, T. N. Rao, J. Reedijk, J. van Rijn and G. C. Verschoor, J. Chem. Soc., Dalton Trans., 1984, 1349.

16 (a) D. F. Evans, J. Chem. Soc., 1959, 2003; (b) S. K. Sur, J. Magn. Reson., 1989, 82, 169.

17 Z. Hu, N. J. Spangler, M. E. Anderson, J. Xia, P. W. Ludden, P. A. Lindahl and E. Münck, J. Am. Chem. Soc., 1996, 118, 830.

18 W. Gu, J. Seravalli, S. W. Ragsdale and S. P. Cramer, Biochemistry, 2004, 43, 9029.

19 D. H. Gibson, Chem. Rev., 1996, 96, 2063.

20 Classification of the $\mu_{2}-\kappa C: \kappa^{2} O, O^{\prime}$ binding modes of $\mathrm{CO}_{2}$ for a bimetallic center $\left(\mathrm{M}\right.$ and $\left.\mathrm{M}^{\prime}\right)$ : while the $\mathrm{CO}_{2}$ coordinates via a $\mathrm{M}-\mathrm{C}$ bond, class I complexes have the two oxygen atoms of the $\mathrm{CO}_{2}$ ligand symmetrically bonded to $\mathrm{M}^{\prime}$ and class II complexes possess two asymmetric $\mathrm{M}^{\prime}-\mathrm{O}$ bonds.

21 (a) D. H. Gibson, J. F. Richardson and T.-S. Ong, Acta Crystallogr., Sect. C: Cryst. Struct. Commun., 1991, 47, 259; (b) D. H. Gibson, M. Ye and J. F. Richardson, J. Am. Chem. Soc., 1992, 114, 9716; (c) D. H. Gibson, J. F. Richardson and O. P. Mbadike, Acta Crystallogr., Sect. B: Struct. Sci., 1993, 49, 784; (d) D. H. Gibson, M. Ye, J. F. Richardson and M. S. Mashuta, Organometallics, 1994, 13, 4559; (e) D. H. Gibson, M. Ye, B. A. Sleadd, J. M. Mehta, O. P. Mbadike, J. F. Richardson and M. S. Mashuta, Organometallics, 1995, 14, 1242; $(f)$ M. Lutz, M. Haukka, T. A. Pakkanen and L. H. Gade, Organometallics, 2001, 20, 2631.

22 (a) S. Kaur-Ghumaan and M. Stein, Dalton Trans., 2014, 43, 9392; (b) A. C. Marr, D. J. E. Spencer and M. Schröder, Coord. Chem. Rev., 2001, 219-221, 1055.

23 (a) S. Ciurli, P. K. Ross, M. J. Scott, S.-B. Yu and R. H. Holm, J. Am. Chem. Soc., 1992, 114, 5415; (b) R. Panda, C. P. Berlinguette, Y. Zhang and R. H. Holm, J. Am. Chem. Soc., 2005, 127, 11092; (c) J. Sun, C. Tessier and R. H. Holm, Inorg. Chem., 2007, 46, 2691.

24 D. Huang and R. H. Holm, J. Am. Chem. Soc., 2010, 132, 4693. 25 (a) D. W. Ovenall and D. H. Whiffen, Mol. Phys., 1961, 4, 135; (b) J. W. Rabalais, J. M. McDonald, V. Scherr and S. P. McGlynn, Chem. Rev., 1971, 71, 73. 